\title{
ANTIOXIDATIVE ACTIVITY OF CHITOSAN AND CHITOSAN BASED BIOPOLYMER FILM
}

\author{
Nevena M. Hromiš*, Vera L. Lazić, Senka Z. Popović, Danijela Z. Šuput, Sandra N. Bulut \\ University of Novi Sad, Faculty of Technology, 21000 Novi Sad, \\ Bulevar cara Lazara 1, Serbia
}

\author{
*Corresponding author: \\ Phone: +381214853702 \\ E-mail address: nevena.krkic@uns.ac.rs
}

\begin{abstract}
Growing consumer demand for the food without chemical preservatives focused significant extent of research in the direction of finding natural compounds that can be used in food preservation. In this context, natural substances with strong antimicrobial and antioxidant properties, like essential oils, as well as natural biopolymers, particularly draw attention. Natural biopolymers can serve as carriers of the active components, such as essential oils in order of their sustained release to the food during storage, and may themselves exhibit activity in protecting foods from oxidation and/or microbial spoilage.

Chitosan has been extensively studied as semi-natural polymer with expressed bioactive properties. While antimicrobial activity of chitosan solution in different acids has been confirmed towards different bacteria, yeasts and moulds, reports concerning intensity, underlying machanism and different factors afecting antioxidant activity of chitosan vary through the available literature. This paper presents a review in the field of antioxidative activity of chitosan with different properties, as well as chitosan based biopolymer films in order to clarify this aspect of chitosan bioactivity and confront different reports found in the literature.
\end{abstract}

Key words: chitosan, chitosan film, antioxidant activity

\section{INTRODUCTION}

Food quality deteriorates through different processes, among which are oxidative processes induced and propagated by atmospheric oxygen. Different parameters of food quality are affected by these processes, as appearance, texture, flavor and odor, as well as nutritional value and safety. The extent of changes depends on the type of food and conditions (Đilas et al., 2002). Oxidation may be inhibited or slowed by removal of air oxygen, use of lower temperature, inactivation of enzyms catalyzing oxydation or using specific additives which inhibit oxidation, belonging to various groups of substances called antioxidants. Chemically very different substances, antioxidants have diverse mechanisms of action and their origin can be natural (synthetyzed by microorganisms, fungi, even animals, and most often by plants) or synthetyc (butylated hydroxyanisole-BHA, butylated hydroxytoluene$\mathrm{BHT}$, propyl gallate-PG, tert-butylhydroquinone-TBHQ) (Pokorný, 2003). However, there has been growing concern over the possible carcinogenic effects of synthetic antioxidants in foods. Thus, BHA is not allowed for food application in Japan and a number of other countries and TBHQ remains disallowed in Canada, 
Japan and Europe. Therefore, there is a general trend to replace synthetic antioxidants with natural ones (Shahidi, 2000).

Chitosan is the name for chitin substituents with low level of acetylation, primarily consisting of glucosamine, 2-amino2-deoxy- $\beta$-D-glucose, or (1-4)-2-amino-2deoxy-D-glucose (Figure 1). The degree of deacetylation ("degree of deacetylationDD") usually ranges from $5 \%$ to $15 \%$ in chitin and from $70 \%$ to $95 \%$ in chitosan.

Deacetylated chitosan has free amino groups, which can be easily positively charged in an acidic medium. This contributes to the solubility of chitosan in aqueous solutions of acids and allows the use of chitosan and its bioactivity. However, due to the production process including deacetylation of chitin, chitosan properties, such as: purity, viscosity, deacetylation degree, the molecular weight and crystalline structure may vary considerably depending on the manufacturing process. For example, the source of chitin may affect the crystallinity of chitin, which continues to affect the bioactivity of produced chitosan (Shahidi et al., 1999).

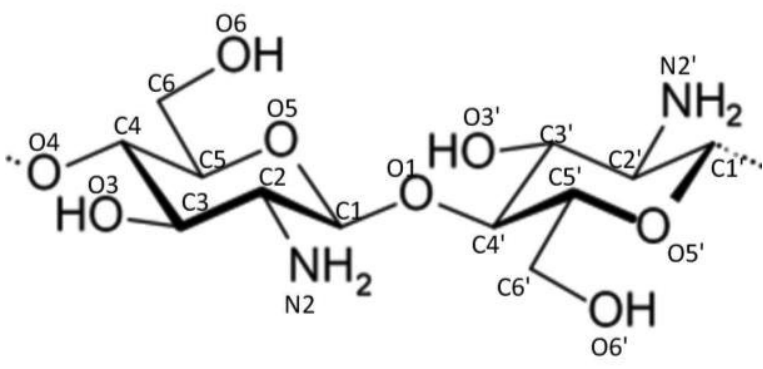

Figure 1. Dimer segment in chitosan molecule

Antioxidant activity is one of the extensively studied functions of chitosan. Different mechanisms of antioxidant action of chitosan have been proposed in the literature: free radicals scavenging ability, inactivation of metal ions by adsorption, ion-exchange and chelation, while for formed biopolymer films, additional mechanisms were reported: low oxygen permeability and forming of stable fluorosphere in reaction of primary amino groups of chitosan and volatile aldehydes, like malondialdehyde. The hydroxyl groups $(\mathrm{OH})$ and amino groups $\left(\mathrm{NH}_{2}\right)$ in chitosan are the key functional groups for its anti- oxidant activity (Weist and Karel, 1992; Kamil et al., 2002; Rajalakshmi et al., 2013).

Reports of antioxidative activity of chitosan and chitosan based biopolymer film vary considerably through the literature, depending on applied method of investigation, chitosan source and properties, like molecular weight, deacetylation degree and concentration. Results vary from no activity, over intermediate to pronounced activity. This is why present review aims to clarify this aspect of chitosan bioactivity and confront different reports found in the literature.

\section{Antioxidants-definition, classification and tests for determination of anti- oxidative activity}

Basic definition of antioxidants implies all substances that, in concentrations that are considerably lower compared to the concentration of the substrate that can be oxidized, decrease in a great extent or prevent substrate oxidation. In wider aspect, antioxidant is an agent that inhibits, prevents or removes oxidative damages of target molecule (Halliwell, 1995).

Based on different action mechanism, antioxidants can be (Babović, 2010; Schreiber, 2012):

1) Primary antioxidants or antioxidants with primary activity, delay initiation phase in chain reaction of free radicals or stop this chain reaction in the propagation phase by donation of hydrogen or electrons to free radicals transforming them to more stable products. They usually react with peroxyl or alkoxyl radical, which are formed during lipid hydroperoxide decomposition.

These antioxidants are efficient in low concentrations, while in higher concentrations they can even show prooxidant activity. Examples of primary antioxidants are: phenols, Trolox-C, anoxomer, BHAButylated hydroxyanisole, BHT-Butylated hydroxytoluene, etoxyquin, galates, flavornoids, rosemary extract, vitamin $\mathrm{E}$, etc.

2) Secondary or preventive antioxidants prevent decomposition of lipid hydroperoxydes to free radicals, ie. they reduce speed of initiation phase in chain reactions 
by different mechanisms of metal inactivation, decomposition of lipid hydroperoxides to non radical products, oxygen removal, binding of certain proteins with prooxidant activity, UV absorption, or (as in the case of phospholipids) by formation of protective layer between oil and air.

Secondary antioxidants do not transform free radicals into more stabile products. Examples of secondary antioxidants are: ascorbic acid, citric acid, phospholipids, carotenoides, sulfur compounds, selenium, transferrin, ceruloplasmin, etc..

3) Synergists do not have antioxidant effects, or have very little effect, but enhance the activity of primary antioxidants.

The synergists include antioxidants that bind oxygen or "scavengers" of oxygen (ascorbic acid, sulfites, ascorbyl palmitate, erythorbic acid) and the metal chelating agents (citric acid, EDTA, phosphates, amino acids, phospholipids, products of Mailard's reaction).

Different classification can also be found in the literature, wherein secondary antioxidants and synergists constitute one group, which is referred to as secondary antioxidants and synergists (Babović, 2010; Schreiber, 2012).

Due to the large number of reactive chemical species that disrupt the quality of lipids in foods and the diversity of their mechanisms of action, it is impossible to define a single measure of antioxidant activity.

In the evaluation process of the antioxidant potential of the test substance, it is necessary to choose a combination of multiple assays based on different principles and inspect antioxidative potential of the test substance by means of various mechanisms of action.

\section{Antioxidative activity of chitosan}

In the literature, various data related to the activity of chitosan, as a primary antioxidant can be encountered.

Analyzing the antioxidant activity of chitosan with degree of deacetylation of 78 $82 \%$, without indication of the molecular weight of chitosan used, Kanatt et al.
(2008) presented the results where chitosan did not show a primary antioxidant activity ('DPPH test, hydroxyl radical and superoxide anion radical scavenging activity, reducing power). Low antioxidant activity ('DPPH test, reducing power and lipid peroxidation inhibition activity) was also shown in the work of Trung and Bao (2015) for the chitosan with DD $87 \%$ and no molecular weight specification. Similar, higher-molecular forms of chitosan (HMW) did not show activity as a primary antioxidants in the work of Pasanphan et al. (2010) and this lack of activity can be correlated with strong intra- and intermolecular hydrogen bonds resulting in the absence of hydrogen atoms that would be donated to break free radicals chain oxidation reactions. Schreiber (2012) argued that chitosan is not a primary antioxidant, and that a possible activity reported in some studies is a consequence of insufficient purification of the chitosan with residue of some components that can show activity.

Tomida et al. (2009) presented the results of the analysis of antioxidant activity of chitosan of various molecular weights (2.8 $\mathrm{kDa}, 17.0 \mathrm{kDa}, 33.5 \mathrm{kDa}, 62.6 \mathrm{kDa}, 87.7$ $\mathrm{kDa}, 604 \mathrm{kDa}, 931 \mathrm{kDa}>>90 \% \mathrm{DD})$ in concentration range from $1 \mathrm{mg} / \mathrm{mL}$ to 8 $\mathrm{mg} / \mathrm{mL}$. Their conclusions were that the chitosan of low molecular weight-LMW $(<30 \mathrm{kDa})$ has strong antioxidant activity, measured as the scavenging ability of 'DPPH (80-100\%) and ${ }^{\circ} \mathrm{ABTS}^{+}$radicals $(70-100 \%)$, as well as the ability to reduce copper ions. Activity was concentration dependent for all tested chitosans. Chitosans with higher molecular weights were much less active in these assays (in a concentration up to $5 \mathrm{mg} / \mathrm{mL}$ ), chitosans with medium molecular weights showed modest activity, while HMW chitosans activity was low (below $50 \%$ of scavenging ability in the concentration range). Based on these results, LMW chitosans could be considered as primary antioxidants, which was not the case with higher-molecular forms. These results are in agreement with Yasufuku et al. (2010) and Al-Hassan (2016). In accordance with these results were the results of Alsharabasy (2016), where LMW chitosans (Mv around 21.5 
$\mathrm{kDa}$ ) showed antioxidant activity above $50 \%$ in protecting linoleic acid from oxidation. Increase in deacetylation degree (DD) of chitosan of same molecular weight led to significant increase in antioxidant activity. Chitosan with DD of $98 \%$ had activity of $78.5 \%$, while activity of chitosan with DD $90 \%$ amounted $51.5 \%$.

Three different HMW chitosans: Mv 659 $\mathrm{kDa}$ and DD 78\%, Mv $1249 \mathrm{kDa}$ and DD $85 \%$ and $\mathrm{Mv} 329 \mathrm{kDa}$ and DD $75 \%$ showed DPPH scavenging ability of about $32 \%, 10 \%$ and $34 \%$; ABTS $^{+}$scavenging activity $22 \%, 11 \%$ and $24 \%$ and nitric oxide scavenging ability of $61 \%, 48 \%$ and $59 \%$, respectively (Walke et al., 2014). Youcefi and Ali Riazi (2014) reported DPPH scavenging ability of HMW chitosan $(75 \% \mathrm{DD}$ and $1718 \mathrm{kDa} / \mathrm{mol})$ in the range $37.66-62.66 \%$ for chitosan concentration $0.5-2 \%$.

Chitosan with high molecular weight (100 $\mathrm{kDa}, 90 \% \mathrm{DD})$ was shown to have antioxidative potential in the systemic circulation in humans. The authors suggest that HMW chitosan lowers levels of prooxidants (lipid hydroperoxides and other pro-oxidants that induce the formation of free radicals) and in this way inhibits oxidative stress (Anraku et al., 2011). This is the principle of operation of the synergist in protection of the substrate from oxidation.

In the work of Wan et al. (2013), activity of HMW chitosan $(1,240 \mathrm{kDa}, 97 \%$ DD) was studied using the scavenging ability of DPPH radicals, hydroxyl radicals and superoxide anion radicals. Chitosan, in the concentration of $0.8 \mathrm{mg} / \mathrm{mL}$ revealed activity of different intensity towards different studied radicals: ${ }^{\circ} \mathrm{O}_{2}{ }^{-}>{ }^{\circ} \mathrm{OH}>$ DPPH. Activity in the capture of ${ }^{\circ} \mathrm{DPPH}$ was of low intensity ( $35 \% \mathrm{AA})$ and was not dependent on the concentration of chitosan, up to $0.8 \mathrm{mg} / \mathrm{mL}$. Based on the results that $\mathrm{N}$-quaternized chitosan derivatives showed higher activity towards 'DPPH, while O-quaternized derivatives showed lower activity compared to the non-derivatized chitosan, authors stated the hypothesis that in the scavenging of DPPH more significant contribution was of hydroxyl groups relative to amino groups.
Within the same group of derivatives, the authors have observed a decrease of activity with increasing molecular weight, which they interpreted as larger number of intramolecular hydrogen bonds that weaken activity of the hydroxyl and amino groups. The antioxidant activity of HMW chitosan, expressed as the scavenging ability of the $\mathrm{OH}$ increased with increase in the chitosan concentration, from 0.11 $\mathrm{mg} / \mathrm{mL}$ to $1.1 \mathrm{mg} / \mathrm{mL}$ and to a lesser extent over time. In the above range of concentrations, the percentage of activity increased from $12 \%$ to $83 \%$. Three mechanisms of ${ }^{\circ} \mathrm{OH}$ scavenging using chitosan molecule were hypothesized. According to the first mechanism, the hydroxyl groups of the polysaccharide react with $\mathrm{OH}$ in a typical abstraction reaction (abstraction of $\mathrm{H}$ atom). The second mechanism involves the reaction of ${ }^{\circ} \mathrm{OH}$ with free amino groups $\left(-\mathrm{NH}_{2}\right)$ to form stable macromolecular radicals, while according to the third mechanism, amino group turns to ammonium group absorbing a hydrogen ion from the solution and thereafter ammonium groups react with the ${ }^{\circ} \mathrm{OH}$ in the addition reaction. Considering all three mechanisms, the greater the number of hydroxyl and amino groups, the greater will be the activity of antioxidant. The authors reported, based on the activities of different derivatives of chitosan, that the activity of the C-2 amino group is more significant than the activity of C-6 hydroxyl group in scavenging ${ }^{\circ} \mathrm{OH}$. Activity of $\mathrm{HMW}$ chitosan in the capture of ${ }^{\circ} \mathrm{O}_{2}^{-}$was minimally dependent on the concentration in the range of $0.4 \mathrm{mg} / \mathrm{mL}$ to $2.4 \mathrm{mg} / \mathrm{mL}$ and ranged from approximately $90 \%$ to $96.5 \%$. Polysaccharides that exhibit scavenging ability of ${ }^{\circ} \mathrm{O}_{2}^{-}$have one or more alcoholic or phenolic hydroxyl groups, and the activity is related to the number of active hydroxyl groups. In addition, the amino group can react with the free radical to form a more stable macroradical. Based on the results of this research, HMW chitosan acts as a primary antioxidant.

Li et al. (2014) reported results in support to the primary antioxidant activity of higher molecular weight chitosan. They have examined the ability of chitosan (78 kDa, 400 $\mathrm{kDa}, 640 \mathrm{kDa}, 97 \% \mathrm{DD})$ to scavenge the 
'OH. The authors found that chitosans of all tested molecular weights showed antioxidant activity of more than $70 \%$, wherein this activity depended on the concentration, time and molecular weight. As already described, due to the mechanism of action, chitosan antioxidant activity increases as chitosan concentration increases. However, with the increase in the concentration, solution viscosity also increases, which leads to a weaker dispersion, diminishing the activity. Basic hydrogen bonds: intramolecular, O3-O5 and intermolecular, N2-O6, amplify with increasing concentration, which weakens the free radical scavenging ability, so there was an optimal concentration, which was established as $0.2 \mathrm{mg} / \mathrm{mL}$ in this paper. With increased molecular weights, intramolecular hydrogen bonds amplify, leading again to decrease in antioxidant activity.

In the paper of Yen et al. (2008), primary antioxidant activity of chitosans of different degree of deacetylation $83.3 \%-88.4 \%$ was confirmed, but molecular weights of chitosans analyzed were not specified in the paper. In the concentration ranging from 0.1 - $10 \mathrm{mg} / \mathrm{mL}$, chitosan showed significant hydroxyl radicals scavenging activity, $60 \%-80 \%$, at the concentration of $0.1 \mathrm{mg} / \mathrm{mL}$ and $88.7 \%-94.1 \%$, at the concentration of $10 \mathrm{mg} / \mathrm{mL}$ (activity increased with increased degree of deacetylation). Also, in the test of conjugated dienes, all chitosans showed antioxidant activity by protecting linoleic acid against oxidation. Activity was comparable to the activity of the ascorbic acid and at the concentration of $1 \mathrm{mg} / \mathrm{mL}$, activity ranged from $58.3 \%$ $70.2 \%$, while at the concentration of 10 $\mathrm{mg} / \mathrm{mL}$, activity was $79.9 \%-85.2 \%$. Scavenging activity of 'DPPH radicals was modest and amounted to a maximum of $50 \%$ at the highest concentration of chitosan. Particularly low scavenging activity of radicals was shown by chitosans with the lowest level of deacetylation. The ability of chitosan to chelate ferrous ions was rather high (like EDTA), and ranged from 82.9\% $96.5 \%$ for chitosan concentration of 1 $\mathrm{mg} / \mathrm{mL}$. The ability of chelating transition metal ions is of great importance for the application of chitosan in food protection from lipid peroxidation. Chelating mechanism is based on binding ions to the hydroxyl group of the C6 atom, as well as to the amino group of the C2 atom. Reducing power of the analyzed chitosans was low and amounted to about one third of the reducing power value that showed $\alpha$ tocopherol, BHA and ascorbic acid (Yen et al., 2008).

Summarizing results presented in the literature, chitosan can be considered as antioxidant agent, but to fulfill the high standards of primary antioxidant, LMW chitosans (below $30 \mathrm{kDa}$ ) with high DD (above $90 \%$ ) should be used. Chitosans with higher molecular weights and/or lower DD can be considered as secondary antioxidants and their activity can be adjusted by using higher concentrations or higher DD. Also, what can be observed through literature survey is that chitosan of all molecular weights show different antioxidant activity in different tests, in the approximate order ${ }^{\circ} \mathrm{O}_{2}{ }^{-}>{ }^{*} \mathrm{OH}>$ protection of linoleic acid against oxidation $>$ 'DPPH. The most frequently used test for antioxidant activity of chitosan, the 'DPPH radical scavenging assay seems to be the least appropriate one, and this is why more different tests should be used when analyzing antioxidant activity in vitro.

\section{Antioxidative activity of chitosan film}

For the antioxidant activity of chitosan films, in the literature, results of the scavenging capacity of DPPH radicals, ${ }^{-} \mathrm{ABTS}^{+}$radicals, reducing power and the ability of chelating ions of the transition metals are most frequently shown. In these tests, usually water or methanol extract of the film is analyzed, so only components of the film able to migrate into water or methanol are involved, and not film as a whole. In the case of chitosan film, these are most probably low molecular fraction of glucosamine, acetic acid and impurities included in the chitosan composition (Lagaron et al., 2007; Schreiber, 2012). Fewer references where found where activity of chitosan film was analyzed with whole film in the contact with the solution of free radical (Table 1).Test results vary from no activity to intermediate activity of chitosan film, mea- 
sured as the ability to scavenge 'DPPH radicals (from no activity to around $40 \%$ ), reducing power (from no activity to 0.55 ) and ability of chelating ferrous ions (about $20 \%$ ).

These results can be attributed to strong intermolecular hydrogen bonds that have already been discussed in concentrated solutions of chitosan, which are even more pronounced in the film, employing reactive groups of chitosan and lowering possibility of expressing the antioxidant potential of the film. In order to improve the antioxidant activity of chitosan film, different authors modified the chitosan molecule by introducing the group with primary antioxidant activity (Schreiber, 2012; Guo, 2015) or added different low molecular weight antioxidants to the film (Table 1).
Guo (2015) increased antioxidant activity of chitosan films by pre-grafting gallic acid or surface grafting of gallic acid via esterification and amidation from no primary activity ( $0 \%{ }^{\circ} \mathrm{DPPH}$ and 0.00 reducing power) to scavenging activity above $50 \%$ (75.3\% and $68.6 \%$, for surface modified films and pre-grafted films respectively), and increased reducing power (2.02 and 1.24, for surface modified films and pre-grafted films, respectively). In the second case, when different LMW anti-oxidants are added to the film, film serves as a carrier of these components, enabling them to be gradually released over time. Some of the active components which were added to the chitosan film, as well as their contribution to the antioxidant activity of chitosan film are shown in Table 1.

\section{Table 1.}

Antioxidant activity of chitosan films containing low molecular weight antioxidants

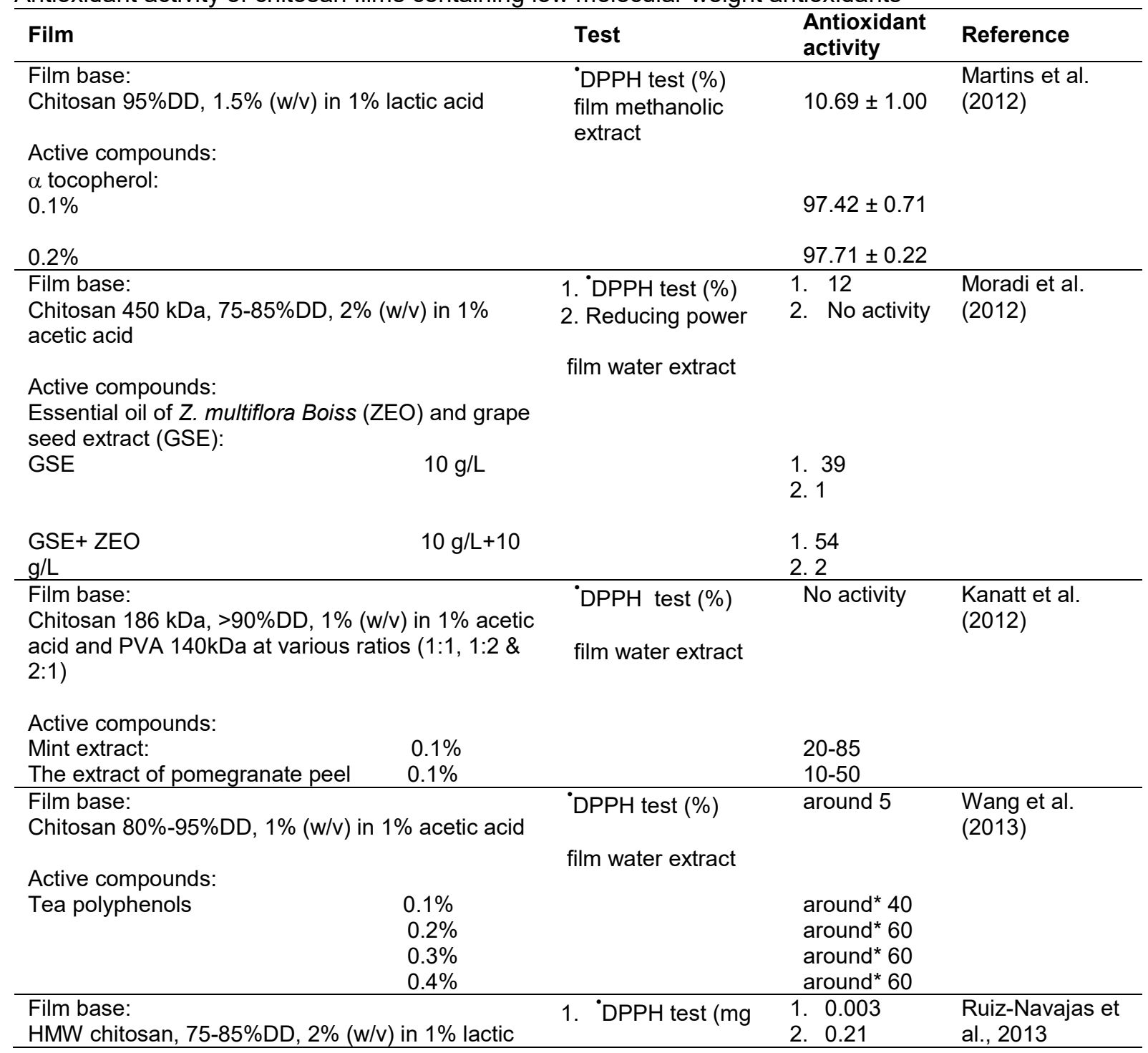




\begin{tabular}{|c|c|c|c|}
\hline acid & $\begin{array}{l}\text { Trolox equivalent/g } \\
\text { of film) }\end{array}$ & 3. around $^{*} 20$ & \\
\hline Active compounds: & 2. FRAP test (mg & & \\
\hline Essential oil of $T$. moroderi $0.5 \%, 1 \%, 2 \%$ & $\begin{array}{l}\text { Troloks eq./g of } \\
\text { film) } \\
\text { 3. } \mathrm{Fe}^{2+} \text { chelating } \\
\text { ability (\%) } \\
\text { film methanolic }\end{array}$ & $\begin{array}{ll}\text { 1. } & 0.42-0.63 \\
\text { 2. } & 0.00-0.67 \\
\text { 3. } & \text { around* } \\
\text { 35 } & \end{array}$ & \\
\hline Essential oil of $T$. piperella $0.5 \%, 1 \%$, i $2 \%$ & extract & $\begin{array}{l}\text { 1. } 0.69-1.09 \\
\text { 2. } 2.79- \\
\text { 10.09 } \\
\text { 3. around* } \\
35\end{array}$ & \\
\hline $\begin{array}{l}\text { Active compounds: } \\
\text { The aqueous extract of grape hooks } 0.15 \%(\mathrm{w} / \mathrm{w}) \\
\text { Wax from grape berry skin } 0.15 \% \text { and } 0.30 \%(\mathrm{w} / \mathrm{w}) \\
\text { Grape seed oil } 0.75 \%(\mathrm{w} / \mathrm{w})\end{array}$ & $\begin{array}{l}\text { 1. } \text { ABTS }^{+} \text {test }(\%) \\
\text { 2. 'DPPH test }(\%) \\
\text { 3. FRAP } \\
(\text { Absorbance in } 595 \\
\text { nm) } \\
\text { 4. reducing power } \\
\text { (absorbance in } 700 \\
\text { nm) } \\
\text { Tests were } \\
\text { performed on whole } \\
\text { film }\end{array}$ & $\begin{array}{l}\text { 1. } 13 \\
\text { 2.around }{ }^{*} 7 \\
\text { 3. around* } \\
0.12 \\
\text { 4. around* } \\
0.55 \\
\text { 1. } 13-30 \\
\text { 2. } 15-35 \\
\text { 3. } 0-0.22 \\
\text { 4. } 0.4-0.6\end{array}$ & $\begin{array}{l}\text { Ferreira et al. } \\
(2014)\end{array}$ \\
\hline $\begin{array}{l}\text { Film base: } \\
\text { Chitosan } 80 \% \mathrm{DD}, 1 \%(\mathrm{w} / \mathrm{v}) \text { in } 1 \% \text { acetic acid } \\
\text { Active compounds: } \\
\text { Caraway essential oil } \quad 1 \%(\mathrm{v} / \mathrm{v}) \\
\text { Oregano essential oil } \quad 1 \%(\mathrm{v} / \mathrm{v})\end{array}$ & $\begin{array}{l}\text { DPPH test }(\%) \\
\text { Tests were } \\
\text { performed on whole } \\
\text { film }\end{array}$ & $\begin{array}{l}30-80 \\
>90\end{array}$ & $\begin{array}{l}\text { Hromiš et al. } \\
(2014)\end{array}$ \\
\hline $\begin{array}{l}\text { Film base: } \\
\text { HMW chitosan, } 75-85 \% \mathrm{DD}, 2 \%(\mathrm{w} / \mathrm{v}) \text { in } 1 \% \text { lactic } \\
\text { acid } \\
\text { Active compounds: } \\
\text { maqui berry extract }\end{array}$ & $\begin{array}{l}\text { 1. 'DPPH test (mg } \\
\text { Trolox equivalent/g } \\
\text { film) } \\
\text { 2. FRAP (mg Trolox } \\
\text { equivalent/g film) } \\
3 . \text { Ferrous ions } \\
\left(\text { Fe }{ }^{2+} \text { ) chelating }\right. \\
\text { activity (mg EDTA } \\
\text { equivalent/g } \\
\text { sample) } \\
\text { film methanolic } \\
\text { extract }\end{array}$ & $\begin{array}{l}\text { 1. } 0.01 \\
\text { 2. } 0.16 \\
\text { 3. } 107.81 \\
\text { 1. } 2.06 \\
\text { 2. } 4.26 \\
\text { 3. } 109.99 \\
\text { 1. } 2.80 \\
\text { 2. } 9.36 \\
\text { 3. } 111.15\end{array}$ & $\begin{array}{l}\text { Genskowsky et } \\
\text { al. (2015) }\end{array}$ \\
\hline $\begin{array}{l}\text { Film base: } \\
\text { Chitosan } 80 \% \mathrm{DD}, 1 \%(\mathrm{w} / \mathrm{v}) \text { in } 1 \% \text { acetic acid } \\
\begin{array}{l}\text { Active compounds: } \\
\text { Caraway essential oil } \quad 1 \%(\mathrm{v} / \mathrm{v}) \\
\text { Caraway essential oil } \quad 2 \%(\mathrm{v} / \mathrm{v}) \\
\text { Caraway essential oil } \quad 3 \%(\mathrm{v} / \mathrm{v})\end{array} \\
\end{array}$ & $\begin{array}{l}\text { DPPH test }(\%) \\
\text { Tests were } \\
\text { performed on whole } \\
\text { film }\end{array}$ & $\begin{array}{l}33.47-81.08 \\
80.38-94.14 \\
92.71-94.83 \\
\end{array}$ & $\begin{array}{l}\text { Hromiš et al. } \\
(2015) \text { a and } \\
\text { Hromiš et al. } \\
(2015) b\end{array}$ \\
\hline $\begin{array}{l}\text { Film base: } \\
\text { Chitosan } 88 \% \mathrm{DD} \text {, viscosity } 51 \mathrm{mPas}, 2 \%(\mathrm{w} / \mathrm{v}) \text { in } \\
1 \% \text { acetic acid }\end{array}$ & $\begin{array}{l}\text { 'DPPH test }(\%) \\
\text { film water extract }\end{array}$ & 3.7 & $\begin{array}{l}\text { Wang et al. } \\
(2015)\end{array}$ \\
\hline $\begin{array}{l}\text { Active compounds: } \\
\text { Lycium barbarum fruit extract } \\
0.4 \% 0.8 \%, 1.2 \%, 1.6 \text { and } 2 \%(\mathrm{w} / \mathrm{v})\end{array}$ & & $\begin{array}{l}\text { around*16- } \\
35.8\end{array}$ & \\
\hline $\begin{array}{l}\text { Film base: } \\
\text { Chitosan, } \geq 75 \% \mathrm{DD}, 2 \%(\mathrm{w} / \mathrm{v}) \text { in } 1 \% \text { acetic acid } \\
\text { Active compounds: } \\
\text { Essential oil of Eucalyptus globulus } 1 \%, 2 \%, 3 \% \text {, } \\
4 \%(\mathrm{v} / \mathrm{v})\end{array}$ & $\begin{array}{l}\text { 1. } \text { DPPH test (\%) } \\
\text { 2. NO scavenging } \\
\text { assay (\%) } \\
\text { 3. } \mathrm{H}_{2} \mathrm{O}_{2} \text { scavenging } \\
\text { assay (\%) } \\
\text { film methanolic } \\
\text { extract }\end{array}$ & $\begin{array}{l}\text { 1. } 10.07 \\
2.19 .04 \\
3.15 .34 \\
1.23 .03- \\
43.62 \\
2.35 .23- \\
70.47 \\
3.27 .4- \\
63.15\end{array}$ & $\begin{array}{l}\text { Hafsa et al. } \\
(2016)\end{array}$ \\
\hline
\end{tabular}




\begin{tabular}{|c|c|c|c|}
\hline $\begin{array}{l}\text { Film base: } \\
\text { Chitosan } 80 \% \mathrm{DD}, 1 \%(\mathrm{w} / \mathrm{v}) \text { in } 1 \% \text { acetic acid }\end{array}$ & 'DPPH test (\%) & $9.3-25.1$ & $\begin{array}{l}\text { Hromiš et al. } \\
(2016)\end{array}$ \\
\hline $\begin{array}{l}\text { Active compounds: } \\
\text { garlic, black pepper, caraway and cinnamon } \\
\text { oleoresins }\end{array}$ & $\begin{array}{l}\text { Tests were } \\
\text { performed on whole } \\
\text { film }\end{array}$ & & \\
\hline $0.8 \%$ & & $46.9-94.0$ & \\
\hline $1.6 \%$ & & $86.3-93.8$ & \\
\hline $2.4 \% \mathrm{w} / \mathrm{v}$ & & $92.9-92.4$ & \\
\hline
\end{tabular}

Different authors tested effect of addition of chemically different compounds and mixtures, like tocoferols (Martins et al., 2012), polyphenols (Wang et al., 2013), plant essential oils and extracts (Moradi et al., 2012; Ruiz-Navajas et al., 2013; Hromiš et al. 2014; Hromiš et al., 2015a; Hromiš et al., 2015b; Hafsa et al., 2016 Kanatt et al., 2012), spice oleoresins (Hromiš et al.; 2016), fruit and different fruit parts extracts (Wang et al., 2015; Genskowsky et al., 2015; Ferreira et al., 2014 Kanatt et al., 2012; Moradi et al., 2012) and grape seed oil (Ferreira et al., 2014). Active compounds were added in different concentrations, from $0.1 \%$ to $4 \%$. Mint extract, $\alpha$ tocopherol, extract of pomegranate peel or of grape hooks, tea polyphenols and wax from grape berry skin were added in the lowest range of $0.1-0.5 \%$ and different antioxidant activity of tested films was obtained: from modest (below $50 \%$ 'DPPH scavenging activity) for the extract of pomegranate peel, over intermediate activity (50-60\% ${ }^{\circ} \mathrm{DPPH}$ scavenging activity) for added tea polyphenols to significant activity (>80\% 'DPPH scavenging activity) when $\alpha$ tocopherol and mint extract were added in the film. Higher concentrations $0.5-2 \%$ were used for different essential oils addition, like: $Z$. multiflora Boiss, T. moroderi, T. piperella, caraway and oregano essential oils, spice oleoresins, grape seed extract, grape seed oil and extracts of maqui berry and Lycium barbarum. Once more, antioxidant activity went from modest, over intermediate to significant activity.

Rarely higher concentrations, $2-4 \%$ of active compounds were used for essential oils of Eucalyptus globules and caraway and resultant activity ranged from intermediate to significant. It can be observed, from the Table 1, that addition of low molecular weight antioxidant substances in- creased activity of chitosan film in specie dependant and concentration dependant manner.

\section{CONCLUSIONS}

Based on the numerous literature studies, general conclusion would be that chitosan can be successfully used as an antioxidant, either as a food additive or as an edible film. Thereby, the activity of chitosan as antioxidant food additive is proportional to the concentration of chitosan, but the influence of molecular weight and degree of deacetylation must be considered. When chitosan edible films are considered, introduction of active groups or low molecular weight compounds addition with antioxidant activity is needed in order to obtain film that could be potentially used as active antioxidant packaging film.

\section{ACKNOWLEDGEMENTS}

This study was supported by the Ministry of Education, Science and Technological Development of the Republic of Serbia, Project No. TR31032

\section{REFERENCES}

1. Al-Hassan, A.A. (2016). Utilization of waste: extraction and characterization of chitosan from shrimp byproducts. Civil and Environmental Research, 8 (3), 117-123.

2. Alsharabasy, A.M. (2016). Semi-synthesis of chitosan with high molecular weight and enhanced deacetylation degree. Polymer Sciences, 2 (2:11), 1-8.

3. Anraku, M., Fujii, T., Kondo, Y., Kojima, E., Hata, T., Tabuchi, N., Tsuchiya, D., Goromaru, T., Tsutsumi, H., Kadowaki, D., Maruyama, T., Otagiri, M., Tomida, H. (2011). Antioxidant properties of high molecular weight dietary chitosan in vitro and in vivo. Carbohydrate Polymers, 83 (2), 501-505.

4. Babović, N. (2010). Supercritical carbon dioxide extraction of antioxidant fractions from selected lamiaceae herbs and their antioxidant activity, 
PhD Thesis, Faculty of Technology and Metallurgy, University of Belgrade, Serbia.

5. Đilas, S., Čanadanović-Brunet, J., Ćetković. G. (2002). Antioxidants in food. Chemical Industry, 56 (3), 105-112.

6. Ferreira, A.S., Nunesa, C., Castrob, A., Ferreirab, P., Coimbra M.A. (2014). Influence of grape pomace extract incorporation on chitosan films properties. Carbohydrate Polymers, 113, 490-499.

7. Genskowsky, E., Puente, L.A, Pérez-Álvarez, J.A, Fernandez-Lopez, J. L., Muñoz, A., ViudaMartos, M.(2015). Assessment of antibacterial and antioxidant properties of chitosan edible films incorporated with maqui berry (Aristotelia chilensis). LWT - Food Science and Technology, 64, 1057-1062.

8. Guo, P. (2015). Gallic acid-grafted chitosan films as antioxidant food packaging, MSc Thesis, University of Tennessee, TN, USA.

9. Hafsa, J., Ali Smach, M., Khedher, M.R.B., Charfeddine, B., Limem, K., Majdoub, H., Rouatbi, S. (2016). Physical, antioxidant and antimicrobial properties of chitosan films containing Eucalyptus globulus essential oil. LWT Food Science and Technology, 68, 356-364

10. Halliwell, B. (1995). Antioxidant characterization: Methodology and mechanism. Biochemical Pharmacology, 49 (10), 1341-1348.

11. Hromiš, N., Bulut, S., Lazić, V., Popović, S., Šuput, D., Markov, S., Vaštag, Ž. Džinić, N. (2015a). Effect of caraway essential oil on the antioxidant and antimicrobial activity of chitosan film. Food and Feed Research, 42 (1), 31-42.

12. Hromiš, N., Lazić, V., Markov, S., Vaštag, Ž., Popović, S., Šuput, D., Džinić, N., Velićanski, A., Popović, Lj. (2015)b. Optimization of chitosan biofilm properties by addition of caraway essential oil and beeswax. Journal of Food Engineering, 158, 86-93.

13. Hromiš, N., Lazić, V., Markov., S., Vaštag, Ž., Popović, S., Šuput, D., Džinić, N. (2014). Improvement of antioxidant and antimicrobial activity of chitosan film with caraway and oregano essential oils. Acta Periodica Technologica, 45, 33-43.

14. Hromiš, N., Lazić, V., Popović, S., Markov, S., Vaštag, Ž., Šuput, D., Bulut, S., Tomović, V. (2016). Investigation of a product-specific active packaging material based on chitosan biofilm with spice oleoresins. Journal of Food and $\mathrm{Nu}$ trition Research, 55 (1), 78-88.

15. Kamil, J.Y.V.A., Jeon, Y.-J., Shahidi F. (2002). Antioxidative activity of chitosans of different viscosity in cooked comminuted flesh of herring (Clupea harengus). Food Chemistry, 79, 6977.

16. Kanatt, S.R., Rao, M.S., Chawla S.P., Sharma A. (2012). Active chitosane polyvinyl alcohol films with natural extracts. Food Hydrocolloids, 29 (2), 290-297.

17. Kanatt, S.R., Chander, R., Sharma, A. (2008). Chitosan and mint mixture: A new preservative for meat and meat products. Food Chemistry, 107 (2), 845-852.

18. Lagaron, J.M., Fernandez-Saiz, P., Ocio, M.J. (2007). Using ATR-FTIR spectroscopy to design active antimicrobial food packaging structures based on high molecular weight chitosan polysaccharide. Journal of Agricultural and Food Chemistry, 55 (7), 2554-2562.

19. Li, H., Xu, Q., Chen, Y.,Wan, A. (2014). Effect of concentration and molecular weight of chitosan and its derivative on the free radical scavenging ability. Journal of Biomedical Materials Research A, 102A (3), 911-916.

20. Martins, J.T., Cerqueira, M.A., Vicente A.A. (2012). Influence of -tocopherol on physicochemical properties of chitosan-based films. Food Hydrocolloids, 27 (1), 220-227.

21. Moradi, M., Tajik, H., Rohani, S.M.R., Oromiehie, A.R., Malekinejad, H., Aliakbarlu, J., Hadian, M. (2012). Characterization of antioxidant chitosan film incorporated with Zataria multiflora Boiss essential oil and grape seed extract. LWT - Food Science and Technology, 46 (2), 477-484.

22. Pasanphan, W., Buettner, G.R., Chirachanchai, S. (2010). Chitosan gallate as a novel potential polysaccharide antioxidant: an EPR study. Carbohydrate Research, 345 (1), 132-140.

23. Pokorný, J. (2003). Introduction. In Antioxidants in Food. Eds. J. Pokorný, N. Yanishlieva, M. Gordon, Woodhead Publishing Limited, Cambridge, England.

24. Rajalakshmi, A., Krithiga, N., Jayachitra, A. (2013). Antioxidant activity of the chitosan extracted from shrimp exoskeleton. Middle-East Journal of Scientific Research, 16 (10), 14461451.

25. Reische, D.W., Lillard, D.A., Eitenmiller, R.R. (2008). Antioxidants. In Food Lipids: Chemistry, Nutrition and Biotechnology, $3^{\text {rd }}$ ed. Eds. C.C. Akoh, D. B. Min, Crc Press, Taylor \& Francis Group, Boca Raton, FL, USA, pp. 409-433.

26. Ruiz-Navajas, Y., Viuda-Martos, M., Sendra, E., Perez-Alvarez, J.A., Fernández-López, J. (2013). In vitro antibacterial and antioxidant properties of chitosan edible films incorporated with Thymus moroderi or Thymus piperella essential oils. Food Control, 30 (2), 386-392.

27. Schreiber, S.B. (2012). Chitosan-gallic acid films as multifunctional food packaging. MSC Thesis, University of Tennessee, TN, USA.

28. Shahidi, F., Kamil, J., Arachchiand, V., Jeon, YJ. (1999). Food applications of chitin and chitosans. Trends in Food Science \& Technology, 10 (2), 37-51.

29. Shahidi, F. (2000). Antioxidants in food and food antioxidants. Nahrung, 44 (3), 158 - 163.

30. Tomida, H., Fujii, T., Furutani, N., Michihara, A., Yasufuku, T., Akasaki, K., Maruyama, T., Otagiri, M., Gebicki, J.M., Anraku, M. (2009). Antioxidant properties of some different molecular weight chitosans. Carbohydrate Research, 344 (13), 1690-1696.

31. Trung, T.S., Bao, H.N.D. (2015). Physicochemical properties and antioxidant activity of chitin and chitosan prepared from pacific white shrimp waste. International Journal of Carbohy- 
drate Chemistry, 2015, Article ID 706259, 6 pages.

32. Walke, S., Srivastava, G., Nikalje, M., Doshi, J., Kumar, R., Ravetkar, S., Doshi, P. (2014). Physicochemical and Functional Characterization of Chitosan Prepared From Shrimp Shells and Investigation of its antibacterial, antioxidant and tetanus toxoid entrapment efficiency. International Journal of Pharmaceutical Sciences Review and Research, 26 (2), 215-225.

33. Wan, A., Xu, Q., Sun,Y., Li, H. (2013). Antioxidant activity of high molecular weight chitosan and N,O quaternized chitosans. Journal of Agricultural and Food Chemistry, 61 (28), 6921-6928.

34. Wang, L., Dong, Y., Men, H., Tong, J., Zhou J. (2013). Preparation and characterization of active films based on chitosan incorporated tea polyphenols. Food Hydrocolloids, 32 (1), 35-41.

35. Wang, Q., Tian, F., Feng, Z., Fan, X., Pan, Z., Zhou, J. (2015). Antioxidant activity and physicochemical properties of chitosan films incorporated with Lycium barbarum fruit extract for active food packaging. International Journal of Food Science and Technology, 50, 458-464.

36. Weist, J.L., Karel, M. (1992). Development of a fluorescence sensor to monitor lipid oxidation. 1. Fluorescence spectra of chitosan powder and polyamide powder after exposure to volatile lipid oxidation products. Journal of Agricultural and Food Chemistry, 40, 1158-1162.

37. Yasufuku, T., Anraku, M., Kondo, Y., Hata, T., Hirose, J., Kobayashi, N., Tomida, H. (2010). Useful extend-release chitosan tablets with high antioxidant activity. Pharmaceutics, 2 (2), 245257.

38. Yen, M.T., Yang, J.H., Mau, J.L. (2008). Antioxidant properties of chitosan from crab shells. Carbohydrate Polymers, 74 (4), 840-844.

39. Youcefi, F., Riazi, A. (2014). Extraction, physicochemical characterization and in vitro antioxidative potential of chitosan in shrimp shell waste from Beni Saf sea. Algeria International Journal of Science and Research, 3 (7), 955959.

\title{
АНТИОКСИДАТИВНА АКТИВНОСТ ХИТОЗАНА И ХИТОЗАНСКОГ ФИЛМА
}

\author{
Невена М. Хромиш*, Вера Л. Лазић, Сенка 3. Поповић, Данијела 3. Шупут, Сандра Н. Булут
}

\author{
Универзитет у Новом Саду, Технолошки факултет, 21000 Нови Сад, \\ Булевар цара Лазара 1, Србија
}

Сажетак: Растући захтеви потрошача за храном без додатих хемијских конзерванаса усмерили су многа истраживања у смеру проналажења природних једињења која се могу користити за конзервисање намирница. У овом контексту, природне супстанце са израженим антимикробним и антиоксидативним својствима, као што су етарска уља и природни биополимери, скрећу посебну пажњу. Природни биополимери могу служити као носачи активних компоненти, као што су етарска уља у циљу њиховог постепеног отпуштања у храну током периода складиштења, а могу и сами показивати активна својства у заштити намирница од оксидације и/или микробиолошког квара.

Хитозан, као полу-природни полимер са израженим биоактивним својствима, интензивно се изучава. Док је антимикробна активност хитозана у растворима различитих киселина потврђена према различитим бактеријама, квасцима и плеснима, подаци о интензитету, механизму деловања и различитим факторима који утичу на антиоксидативну активност хитозана варирају у доступној литератури. Овај рад представља преглед у области антиоксидативног деловања хитозана различитих својстава и биополимерних филмова на бази хитозана, са циљем приказивања овог аспекта биолошке активности и суочавања различитих ставова приказаних у литератури.

Кључне речи: хитозан, хитозански фрилм, антиоксидативна активност

Received: 12 April 2017

Accepted: 21 August 2017 